\title{
The Translatability of Indonesian Modality into English
}

\author{
Made Susini \\ Warmadewa University, Bali, Indonesia \\ Ida Bagus Putra Yadnya \\ Udayana University, Bali, Indonesia \\ Ida Ayu Made Puspani \\ Udayana University, Bali, Indonesia
}

\begin{abstract}
Translation is a bilingual activity and the languages involved in translation have their own lexicogrammatical features. Modality which can be categorized into modalization and modulation refers to grammatical realization of interpersonal meaning. Systems of modality are different among languages and these differences become important to be well handled in translation. This research is focused on the translatability of modality from Indonesian into English. It investigates the effects of translation strategies applied by the translator to the contextual meaning of target text that is identified and analyzed from the perspectives of type, value, and orientation of modality based on Halliday's Systemic Functional Grammar. The result shows that modality in Indonesian can be rendered into English. Shifts due to the value or orientation of modality cause differences of the contextual meanings between Indonesian and English texts.
\end{abstract}

Index Terms - translatability, modality, modalization, modulation

\section{INTRODUCTION}

Interlingual translation involves intercultural communication and social action because different languages carry cultural baggage, which represents particular cultural values. These cultural values entail how social actors practice particular socio-cultural activities. In the context of translation in practice, translators as the readers of source texts and as the producers of target texts have important role in transmitting the message because they are often faced with mismatch of grammatical rules and cultures between the source and the target texts. The languages involved in translation have their own lexico-grammatical features. The lexico-grammar selected while translating has to be linked to the context of situation and context of culture of the text (Xia, 2015). It also has to correspond to the purpose of the text, whether it is used to express ideational meaning, interpersonal meaning or textual meaning. So, all grammatical realizations have function in language used. Referring to the function of language reflecting product promotion, Jianjung, Bao, Liu\&Mang (2015) have investigated that to achieve the same effect to the target readers through advertisements, grammatical realizations chosen differ between Chinese and English.

Modality as the grammatical realization to express interpersonal meaning refers to the speaker's judgement, or request of the judgement of the listener, on the status of what is being said (Halliday\&Matthiessen, 2014, p.172). Every language has its own modality system and this needs to be considered in translation. This paper deals with the problems how Indonesian modality is rendered into English. The modality system of Indonesian is different from that of English. Modality in Indonesian is not expressed by using a specific marker but it is lexicalized by using 'selalu', 'mesti', 'hendaknya', and some others, while modality in English is manifested by using a specific modality marker, such as by using modal verbs 'may', 'will', 'must', etc. It can also be expressed by using modal adverbs, such as 'probably', 'certainly', or even by using noun, adjective and any lexical verb.

In its use modality is also influenced by context of situation and context of culture. Different modality marker will have different value and causes different strength. This is also a common problem faced by the translators when they are translating modality from Indonesian into English. Bell (1991) describes:

Clearly, it is essential for the translator to be able to recognize the strength with which the writer of the SLT holds an opinion and to be able to render that in an appropriate manner in the TLT (p.146).

The difference in modality systems of the two languages including problems on the strength of modality causes the translator to make some adjustment linguistically, semantically, and stylistically. So, when translation involves the case of modality, it must be re-contextualized in TL (House, 2015). This re-contextualization may lead to changes of types and value of modality used in target texts (Moindjie, 2015; Lian\&Jiang, 2014). To bridge the different systems of modality of the two languages involved, the translator must be able to function as a mediator and needs a kind of translation choices that the problems faced are successfully handled. This study is to find out the translatability of Indonesian modality and choices which can be adopted to translate Indonesian modality into English. Other studies on 
modality in translation have been conducted by other researchers but their goals did not include drawing translation choices from Indonesian into English (Moindjie, 2015; Lian\&Jiang, 2014). This is what makes this present study differ from other studies.

\section{LITERATURE REVIEW}

Translation is basically a process of realization of meaning which involves choices of different language resources. Systemic Functional Linguistics (SFL) is applicable to be used to handle translation studies because this theory provides us with a way of describing lexico-grammatical choices from the system of wording that enables us to see how language is used to realize meaning. This theory concerns with language use, where language is viewed as embedded in culture. Language use varies according to different contexts which include context of situation and context of culture. Context of situation is seen as comprising three components which include 'Field', 'Tenor', and 'Mode'. These contexts of situation affect the language use since they are linked to the three functions of language called metafunctions of language (Halliday\&Matthiessen, 2014). These metafunctions of language include ideational function, interpersonal function, and textual functions.

Ideational meaning conveys the user's experience of the external world of the sense and the inner world of the mind. Interpersonal meaning displays the speaker's relationship with others to whom the messages are being addressed. This present study is dealing with the interpersonal meaning because it relates to the relationship between the speaker and the listener. It is to investigate the speaker's judgement, or request of the judgement of the listener, on the status of what is being said. In its realization interpersonal meaning is manifested by particular linguistic resources which include MOOD and modality.

\section{A. Mood}

The term of MOOD is used to refer to the name of the primary interpersonal system of the clause. That is the gramaticalization of the semantic system of speech functions. As a system of the clause, there are Indicative and Imperative MOOD. Indicative MOOD is either declarative or interrogative and an interrogative clause is either yes/no type or WH-type. e.g. he always visits me every Sunday shows an indicative MOOD. In relation to interpersonal meaning, Halliday\&Matthiessen (2014) make difference between MOOD and other terms, such as Mode and Mood.

Mode refers to an interpersonal system of the verb (verbal group). It is applied to inflectional systems of the verb. It involves interpersonal contrast of Indicative, Subjunctive, and Imperative. If I were you, I would not do that. It shows something unreal, so it is in subjunctive Mode.

Mood is the name of an element of the interpersonal structure of the clause. The structure is formed by two elements, they are Mood and Residue. The Mood consists of two parts: (a) the Subject, which is nominal group, and (b) Finite operator, which is part of verbal group. For example:

\begin{tabular}{|l|l|l|}
\hline the duke & Has & given that teapot away \\
\hline Subject & Finite & \multicolumn{1}{|c|}{ Residue } \\
\cline { 1 - 1 } Mood
\end{tabular}

\section{B. Modality}

Modality refers to the speaker's judgement, or request of the judgement of the listener, on the status of what being said. Modality belongs to mood Adjunct and mood Adjunct is a type of modal Adjunct. In interpersonal clause structure, the location of modality is in Mood or Comment. For example, the position of might which functions as modality can be seen in the following example.

\begin{tabular}{|l|l|l|l|}
\hline I & might & do & it \\
\hline Subject & Finite & Predicator & Complement \\
\hline Mood & Residue \\
\hline
\end{tabular}

Mood as a part of interpersonal clause structures is formed by Subject and Finite operator, which is a part of a verbal group (Halliday\&Matthiessen, 2014, p. 140). Dealing with Finite verbal operator of a clause, it involves two systems, they are polarity and modality. Polarity refers to the opposition between positive and negative. Modality refers to the area of meaning that lies between yes and no - the intermediate ground between positive and negative polarity (Halliday\&Matthiessen, 2014, p.691). Modality does not only refer to modal verbs such as 'can/could', 'may/might', it can be extended to any lexical verb. Modality is manifested in two ways: modalization and modulation.

Modalization operates on propositions, in the space between 'It is so' and 'It isn't so'. It concerns degrees of probability (including certainty): 'possibly'/'probably'/'certainly' or degrees of usuality: 'sometimes'/'usually', 'always'. Probability and usuality can be expressed in the same three ways:

(a) by finite modal operator in verbal group, e.g. He will come.

(b) by a modal Adjunct of probability or usuality, e.g. He probably comes.

(c) by a combination of the two, e.g. He'll probably come.

Modulation concerns degrees of obligation (including permission): 'allowed to'/'supposed to'/'required to' or 
degrees of inclination: 'willing to'/'anxious to'/'determined to'. Both obligation and inclination can be expressed in two ways:

(a) by a finite modal operator, e.g. You should know that I'll help them.

(b) by an expansion of the Predicator, e.g. You are supposed to know that (by a passive verb).

Further, 'inclination' and 'ability' are included in 'readiness', as mentioned by Halliday\&Matthiessen (2014):

..., we could recognize a general category of 'readiness', having 'inclination' and 'ability' as subcategories at one end of the scale (can/is able to as 'low'-value variants of will/is willing to) (p.696).

In addition to these two types of modality, modality can also be viewed from the explicitness of the speaker presented in an utterance. When the speaker is present explicitly in the utterance, the modality orientation will be subjective, as found in I will pay for it. If not, it is objective, as in Mary probably knows. Based on the way how modality is expressed in the grammatical organization, the orientation of modality can be explicit or implicit. When modality is expressed in grammatical metaphor, its orientation is explicit. Explicit modality is found in It's likely that Mary knows opposed to Mary probably knows which is implicit. If it is attached to modal judgement, the value of modality can be high, median, or low. You must pay for it realizes high obligation, you might pay for it, a low probability. The following is an example of a model for probability realization (Martin and White, 2005, p.15).

\begin{tabular}{|ll|ll|}
\hline objective & & $\begin{array}{l}\text { subjective: } \\
\text { explicit }\end{array}$ & $\begin{array}{l}\text { subjective: } \\
\text { implicit }\end{array}$ \\
\hline high & perhaps & I suspect & might \\
median & probably & I believe & would \\
low & certainly & I know & must \\
\hline
\end{tabular}

\section{Modality in Indonesian}

Modality in Indonesian is also used to refer to the speaker's attitude. Alwi (1992, p.26) categorized modality in Indonesian into intentional, epistemic, deontic, and dynamic modality. All of these kinds of modality are not expressed grammatically but lexicalized by using a specific lexical item. Intentional modality is expressed by using lexical items among those are 'ingin', 'hendak', 'mau', 'akan'; epistemic modality by using 'boleh', 'mungkin', 'barangkali', 'harus', 'mesti'; deontic modality by using 'bisa', 'boleh', 'harus', 'wajib'; and dynamic modality by using 'dapa't, 'bisa'.

Modality in Indonesian can be expressed by using verbs, as in Saya harapkan Ani dan Ali berbahagia or by using adverb, as in Semoga mereka menerima usul Saudara (Alwi, 1992, p.63-65). Arka (2016) in his Proceedings of the International Workshop on TAM and Evidentiality in Indonesian Languages mentions that modals in Indonesian do not impose syntagmatic restriction on the form of the following verb. The example given is: Mereka bisa/ harus/ pasti (sudah) datang. The form of the verb 'datang' is not influenced by the modals bisa', 'harus', 'pasti' or 'sudah' which come before it.

In its function to express the speaker's judgement, modality in Indonesian is also used to express possibility, probability, certainty, usuality, obligation, and inclination. Dealing with this present study, modality in Indonesian is classified based on the modality types proposed by Halliday\&Matthiessen (2014).

\section{Translation Strategies}

In translation meaning is the kingpin (Bell, 1991, p.79). Meaning is transferred in translation through language and can be identified through the lexico-grammatical elements of the text. Text to be translated sometimes expresses modality. According to Hatim and Mason (1997, p.23) modality reflects the attitude towards the status of what is expressed and is linked to the social institutions and processes involved via the notion of social distance. This attitude can be identified from the lexical items of modality used.

The degree of modality within texts, including translation, can indicate the subjective opinion towards the topic of the text. The lack of modality within text indicates that there is a lack of emotional or subjective reasoning towards the events within the text. How modality is translated depends on the strategies applied by the translator. The translation strategies include equation, substitution, divergence, convergence, amplification, reduction, diffusion, condensation, and reordering (Malone, 1988). Because Indonesian and English are languages of different culture, the strategies applied by the translator will influence the result of the target text. So, whatever decided by the translator will have consequence to the contextual meaning of the TT. The changes of contextual meaning which occur can be identified from the type, value, and orientation of the modal used.

\section{MEthods}

The data of this descriptive qualitative study were selected from an Indonesian book on meditation entitled ButirButir Kebijaksanaan: Titian Hidup Sehat dengan Meditasi Bio-Energi Ratu Bagus (Ida Pandita Mpu Nabe Parama Daksa Natha Ratu Bagus, 2012) and its translation in English entitled Pearls of Wisdom: The Path of a Healthy Life with Ratu Bagus Bio-Energy Meditation (Stacey, 2014). They were investigated at clause level and analyzed by applying a descriptive-analytic method. The source clauses expressing modality were presented and the lexical items conveying modality meaning were identified. In terms of modality analysis, the description was carried out by identifying the degrees of possibility, usuality, obligation, and readiness; the value and the orientation. They were then 
analyzed by linking them with situational and cultural contexts. In terms of translation analysis, both texts were compared to examine whether the source and target texts are equivalent and whether there is a kind of change of contextual meaning in this translation due to the translation strategies applied (Saldanha\& O'Brien, 2014, p.83; House, 2015, p.143). All possible translations of the source text modality imply their translation choices.

\section{RESULT AND DiSCUSSION}

Various lexical items expressing modality are used in Indonesian text of meditation. They include 'dapat', 'mungkin', 'akan', 'dipastikan', 'selalu', 'sering', 'senantiasa', 'hendaknya', 'mesti', 'harus', 'seharusnya', 'semestinya,' bisa', 'mampu', 'ingin,' 'berniat', 'memang'. Due to the translation strategies adopted by the translator, there are various ways used to express this modality in English. Some are in the forms of modal verbs which include 'can', 'will', 'may', 'should', 'must'. The others are in modal adverbs, such as 'often', 'always', 'rarely'; in adjective, such as 'possible '; in lexical verb, such as 'want'; or without any modality marker. Modality analysis focuses on three factors: type, value, and orientation. When modality of the ST and TT is of different type and has different value or orientation, this means that changes of contextual meaning occur in the translation of the texts under study. The following table illustrates the Indonesian modality when translated into English found in the texts under study.

TABLE I.

INDONESIAN MODALITY AND ITS ENGLISH REALIZATIONS

\begin{tabular}{|c|c|c|c|c|c|}
\hline \multicolumn{3}{|c|}{ INDONESIAN MODALITY } & \multicolumn{3}{|c|}{$\begin{array}{r}\text { ENGLISH MODALITY } \\
\end{array}$} \\
\hline Types & Strength & Represented by & Manifested by & Strength & Types \\
\hline \multirow{9}{*}{$\begin{array}{l}\text { Probability/ } \\
\text { Certainty }\end{array}$} & med & bisa & can & low & \multirow{10}{*}{$\begin{array}{l}\text { Probability/ } \\
\text { Certainty }\end{array}$} \\
\hline & \multirow[t]{4}{*}{ med } & \multirow[t]{4}{*}{ akan } & can & low & \\
\hline & & & will & med & \\
\hline & & & may & low & \\
\hline & & & no marker & & \\
\hline & med & dapat & can & low & \\
\hline & low & mungkin & possibly & low & \\
\hline & high & dipastikan & no marker & & \\
\hline & high & memang & however & high & \\
\hline \multirow[t]{7}{*}{ Usuality } & \multirow[t]{2}{*}{ med } & \multirow[t]{2}{*}{ sering } & likely & med & \\
\hline & & & often & med & \multirow[t]{6}{*}{ Usuality } \\
\hline & \multirow[t]{3}{*}{ high } & \multirow[t]{3}{*}{ selalu } & always & high & \\
\hline & & & still & & \\
\hline & & & no marker & & \\
\hline & high & senantiasa & no marker & & \\
\hline & low & jarang & rarely & low & \\
\hline \multirow[t]{11}{*}{ Obligation } & \multirow[t]{3}{*}{ high } & \multirow[t]{3}{*}{ mesti } & have/has to & high & \multirow[t]{11}{*}{ Obligation } \\
\hline & & & must & high & \\
\hline & & & will (definitely) & med & \\
\hline & \multirow[t]{3}{*}{ med } & \multirow[t]{3}{*}{ semestinya } & no marker & & \\
\hline & & & should & med & \\
\hline & & & need & high & \\
\hline & \multirow[t]{2}{*}{ high } & \multirow[t]{2}{*}{ harus } & have/has to & high & \\
\hline & & & need & high & \\
\hline & \multirow[t]{2}{*}{ med } & \multirow[t]{2}{*}{ seharusnya } & no marker & & \\
\hline & & & should & med & \\
\hline & low & hendaknya & should & med & \\
\hline \multirow[t]{5}{*}{ Ability } & \multirow[t]{3}{*}{ high } & \multirow[t]{3}{*}{ татри } & can & low & \multirow[t]{5}{*}{ Ability } \\
\hline & & & able & high & \\
\hline & & & no marker & & \\
\hline & \multirow[t]{2}{*}{ med } & \multirow[t]{2}{*}{ bisa } & can & low & \\
\hline & & & able & high & \\
\hline Inclination & med & ingin & want & & Inclination \\
\hline & high & berniat & have intention & & \\
\hline
\end{tabular}

\section{A. Probability}

To express modality of probability, Indonesian uses lexical items, such as 'bisa', 'akan', 'dapat', 'mungkin', 'dipastikan', 'memang'. To indicate probability in English, in some cases the translator decides to use 'can', 'will', and also 'may' to achieve adequate translation. In others, no specific marker is used to signal probability. When the TT also uses modality marker to express probability, it means that the TT also encodes the sense of uncertainty. The writer of the TT avoids giving advice with absolute certainty.

ST: Dari kaca mata biasa kita melihat penyakit tersebut menjadikan kita sengsara dan bahkan menyebabkan ketakutan yang luar biasa. Tetapi dari kaca mata spiritual, penyakit tersebut bisa menjadi obat bagi jiwa (Ida Pandita Mpu Nabe Parama Daksa Natha Ratu Bagus, 2012, p.6). 
TT: Looking through our normal eyes we can see that this illness makes us miserable and causes great fear. But seen through our spiritual eyes, it can become medicine for our Soul (Stacey, 2014, p.6).

To establish probability meaning in the TT, 'bisa' in the ST is expressed by using modal verb 'can'. The modality element in the ST is word-for-word translated into the TT by applying strategy of equation. Based on the context of the ST ' $b i s a$ ' is categorized as median, implicit, objective modality. In the TT 'can' is as a low, implicit, objective modality. This shows that modality in the ST and TT is expressed with the same orientation. Both are objective because the speaker is not explicitly expressed in the utterance in both texts. But, in terms of the value, there is change of value in this translation. Modality in median value in the ST becomes low value in the TT. In terms of its interpersonal meaning, the ST indicates that the speaker is neither too assertive nor too committed in relation to the advice given, while in the TT there is the lack of confidence of the speaker in giving advice.

ST: Pranāyama yang dilakukan dengan maximal akan memberikan dampak kesehatan, karakter, dan spiritual. Segala hal yang sifatnya negatif bisa dihilangkan (Ida Pandita Mpu Nabe Parama Daksa Natha Ratu Bagus, 2012, p.32).

TT: Pranayama, when practiced with maximum concentration, has an impact on heart, character and spirituality. All negative characteristics can be cleared (Stacey, 2014, p.32).

The modality lexical item 'akan' which is used to express probability in the ST is not explicitly transferred into the TT by using modal verb since the translator applied strategy of reduction in this translation. There is also a change of view point. A kind of shift in term of the degree of probability occurs. 'Akan' which belongs to probability modality is turned into certainty modality when it is translated directly. The ST shows a low, explicit, objective probability. Modality of certainty in the TT has a high value. The source text means that what is expressed is possible to happen. In target language, the text has an indication that what is expressed is something which is believed to happen or there is a kind of certainty about the advice given.

ST: Orang yang selalu menggunakan pikirannya, tenaga mereka akan terkuras terus. Jika mereka sakit, maka akan lama sembuhnya. Mari kita selalu memikirkan jiwa, dan kita akan sehat selamanya (Ida Pandita Mpu Nabe Parama Daksa Natha Ratu Bagus, 2012, p.9).

TT: The people whose minds are always busy feel constantly exhausted. Let's stay mindful of our Soul and we will stay healthy for a long time (Stacey, 2014, p.9).

In the ST modality of probability is characterized by the use of 'akan'. The strategy of equation is also adopted in this translation. In the TT this modality item is translated literally into modal verb 'will'. Modality lexical item used in ST is implicit modality and 'will' in the TT is also implicit modality. The modality markers used in both texts are of the same value. Both are of median value. To express the same meaning, the TT uses modal verb with the same orientation. Both texts come with objective modality because the speaker is not explicitly presented in the utterance. Seen from its interpersonal meaning, the two texts indicate that the speaker is neither too assertive nor too committed in giving advice. The followings are also examples expressing probability modality which are translated by the strategy of equation.

ST: Penyembuhan biasa akan terasa sangat nyaman, tetapi sebaliknya dengan penyembuhan sinar suci akan terjadi reaksi yang luar biasa (Ida Pandita Mpu Nabe Parama Daksa Natha Ratu Bagus, 2012, p.17).

TT: Normal healing may feel very comfortable, in contrast to healing with Sacred Light, which can bring about extraordinary reactions (Stacey, 2014, p.17).

\section{B. Usuality}

To express usuality, Indonesian text of meditation uses 'selalu', 'sering', 'senantiasa', 'jarang'. In English some are translated into modal adverbs 'often', 'always', some others are not explicitly translated using modality markers.

ST: Arti hakiki dari sebuah latihan adalah disiplin. Seperti jam, di manapun ditaruh dia akan tetap bekerja seperti fungsinya dengan cepat. Mereka yang selalu dalam koneksi dengan Meditasi Bio Energi cara kerjanya sama dengan jam tersebut (Ida Pandita Mpu Nabe Parama Daksa Natha Ratu Bagus, 2012, p.16).

TT: The true meaning of any training is discipline. Take a watch - whatever it is put, it will continue to work according to its inbuilt mechanism. Anyone connected to Bio-Enegy Meditation will act just like this watch (Stacey, 2014, p.16).

The source text which comes with 'selalu' expresses usuality modality. It is a kind of high, objective, implicit modality. The modality lexical item used indicates that what is conveyed is something which is usually done by all people. Although the speaker feels certain about what is expressed through the use of a high modality, but there is a kind of irresponsibility of the speaker. The speaker is not explicitly mentioned in the utterance that the advice given sounds that it is not his. In the TT the usuality meaning is not expressed by using modality marker. The translator decides to change the view point by using the strategies of reduction and reordering. The clause is represented by using simple present in passive form represented by (who is) connected'. Since the TT does not occur with modality marker, this translation implies that usuality meaning expressed in the source text is higher in value than the one in the target text. The TT with no modality marker will mean that the advice given is intended to be general. Shift of value then occurs in this translation.

ST: Kita semua adalah satu, yang merupakan anak-anak Tuhan. Oleh karena demikian Ratu selalu mengajarkan kepada kita untuk selalu berpikir positif. Setiap kejadian yang terjadi kita jangan sampai lepas dari berpikir positif (Ida Pandita Mpu Nabe Parama Daksa Natha Ratu Bagus, 2012, p.6). 
TT: We are all one, children of God. This is why Ratu always teaches us positive thinking. Whatever happens to you, never stop being positive(Stacey, 2014, p.6).

Modality of usuality in Indonesian text is characterized by the use of modality lexical item 'selalu'. Based on the context, this modality item indicates a high, implicit, subjective modality. In the TT the expression of usuality modality by using 'always'is also in high value and with subjective implicit orientation. Ratu used in the ST and TT refers to the speaker of the utterance. That is why the modality in the texts is subjective modality. This translation shows that the usuality content of Indonesian is successfully transferred into English by using the strategy of equation.

ST: Sering kita bicara banyak terhadap hal-hal kecil, dan ini seolah menjadi mimpi buruk buat kita. Mere bicara panjang lebar di depan umum atau di depan orang, tetapi tidak tahu yang esensial (Ida Pandita Mpu Nabe Parama Daksa Natha Ratu Bagus, 2012, p.5).

TT: We often engage in a lot of small talk and this can turn into a nightmare for us. People talk at length during a speech or in conversation with a person, but the miss the essential point, ... (Stacey, 2014, p.5).

Source text has usuality modality characterized by modality lexical item 'sering'. It belongs to a median, objective, implicit modality. The translator applied equation strategy or word-for-word translation by rendering the modality item 'sering 'into 'often'. In this context 'often' also belongs to a median, objective, implicit modality. In the ST and TT, the speaker positions himself as neither too assertive nor too committed in relation to the advice given which is characterized by median and objective modality. Through word-per-word translation, the two texts are considered equivalent in terms of the interpersonal meaning.

\section{Obligation}

Modality expressing obligation found in Indonesian text is characterized by the use of modality markers which include 'mesti', 'semestinya', 'harus', 'seharusnya', 'hendaknya'.

ST: Waktu ini sangat mahal, demikian juga hidup sangat mahal. Oleh karena itu kita mesti bisa bagaimana menghargai hidup ini. Hidup ini penuh dengan tantangan (Ida Pandita Mpu Nabe Parama Daksa Natha Ratu Bagus, 2012, p.10).

TT: The time now is very precious, therefore life is also very precious. For this reason we must value this life. Life is full of challenges (Stacey, 2014, p.10).

Modality showing obligation occurs in the source text characterized by the use of modality item 'mesti'. 'Mesti' has high value and in this context it belongs to objective and implicit modality. Seen from the strategy applied by the translator, this lexical item expressing modality is literally translated, i.e. by rendering it into 'must'. 'Must' also belongs to high, implicit and objective modality. From modality meaning, both texts are equivalent. Both texts express the same meaning in that there is a kind of power inequality between the speaker and the participants joining the meditation.

ST: Tetapi jika kematian telah menghampiri kita kesusahan itupun sirna bersama nafas yang berhembus terakhir. Jadi apakah mesti kita susah saat hidup (Ida Pandita Mpu Nabe Parama Daksa Natha Ratu Bagus, 2012, p.38)?

TT: But when death is approaching, our troubles will disappear together with our last breath. So, do we have to have difficulties while we are alive (Stacey, 2014, p.37)?

Modality expressing obligation is also found in the ST which is characterized by the item 'mesti'. It has high value. In this context it has objective orientation because the speaker is not explicitly expressed. This modality marker also has implicit manifestation. In this translation, modality of the ST is literally translated into 'have to'. This modality marker also belongs to a high, implicit, objective modality. In terms of personal meaning, both texts express the same meaning. The use of high modality in both texts implies that there is a kind of power inequality between the speaker and the participants who join the meditation.

ST: Latihan bersama akan memberikan dampak yang luar biasa untuk perluasan kesadaran kita. Setiap orang semestinya senantiasa mengisi diri sejak usia masih muda (Ida Pandita Mpu Nabe Parama Daksa Natha Ratu Bagus, 2012, p.2).

TT: Shaking together in a group has an extraordinary impact on expanding our consciousness. We all need to recharge ourselves from an early age (Stacey, 2014, p.2).

'Semestinya' in the ST is used to express obligation. Based on the context, this modality lexical item has median value with implicit and objective orientation. By the strategy of equation, in the TT this obligation modality is expressed by using the verb 'need'. It has low value with implicit and objective orientation because the clause is in simple present tense which shows that it indicates a habitual action. This translation shows that there is a kind of shift of modality value. The speaker of the TT softens his way in giving obligation to the hearers. But, in terms of how the speaker is presented in the utterance, both texts have objective modality because the speaker is not explicitly mentioned.

ST: Tetapi jika kita mendengarkan kata Ratu yang terkadang membuat tersinggung, itu artinya ego yang ada di dalam tubuh harus dilenyapkan (Ida Pandita Mpu Nabe Parama Daksa Natha Ratu Bagus, 2012, p.5).

TT: If occasionally Ratu's words upset us, it shows that our ego needs to be brushed aside (Stacey, 2014, p.5).

The lexical item used to express obligation modality in ST is 'harus'. It has high value. The orientation is implicit, objective. Through literal translation, in TT this modality lexical item is not explicitly expressed by using modal verb. The obligation modality is represented by the use of the verb 'need'. This expresses a kind of habitual action. So, the value becomes low and this indicates that the speaker of the TT displays less authority in giving advice. In accordance 
to the modality orientation, the ST and TT show objective and implicit modality. This means that the speaker of the text avoids mentioning himself/herself in the text to make a symmetrical relation between the speaker/writer and the listeners/readers.

ST: Hal yang paling signifikan juga di sini adalah bagaimana semestinya setiap orang harus menjauhkan diri dari sifat lembam dan malas. Melalui motivasi-motivasi setiap orang hendaknya sadar bahwa dirinya harus energik dan kreatif (Ida Pandita Mpu Nabe Parama Daksa Natha Ratu Bagus, 2012, p.2).

TT: More importantly, we can also overcome traisol lassitude and laziness. With repeated motivation everybody should become aware that we have to be energetic and creative (Stacey, 2014, p.2).

In Indonesian modality of obligation can be expressed by modality lexical item 'hendaknya'. In English this marker is translated into modal verb 'should'. These two markers show the same value, i.e. they have median value. Both are also in implicit objective orientation since the speakers are not mentioned in the utterance. This translation indicates that both texts are equivalent. By using obligation marker 'hendaknya' in the ST and 'should' in the TT which belong to implicit, objective orientation, this means that the speaker does not show power of inequality in giving obligation. The following is another example expressing modality of obligation with the strategy of equation.

ST: Memang, untuk menerima ajaran guru, sisya harus kreatif atau menyamakan frekwensi dengan guru (Ida Pandita Mpu Nabe Parama Daksa Natha Ratu Bagus, 2012, p.7).

TT: To understand this teaching, however, the student has to be creative or tune into the frequency of the teacher (Stacey, 2014, p.7).

\section{Ability}

Modality showing ability in Indonesian is expressed by markers such as 'mampu', 'bisa'. In English this modality showing ability is expressed by the use of modal verb 'can', adjective 'be able', and in some cases it is expressed through simple present tense.

ST: Sekali kita mampu memberikan makan pada jiwa, maka penyakit yang lain tidak berani muncul (Ida Pandita Mpu Nabe Parama Daksa Natha Ratu Bagus, 2012, p.11).

TT: Once we are able to feed our Soul, then our illness no longer has the courage to raise its head (Stacey, 2014, p.11).

'Mampu' in the ST is used to express ability. It has high value and in this context it shows objective and implicit modality. In its translation, this modality lexical item is transferred by using 'be able to'. Basically, both texts are equivalent in terms of their modality content because both texts have objective, implicit and high modality. Both texts imply that in the utterance the speakers are confident enough about what they are talking about.

ST: Dari seluruh jenis olah raga yang paling baik, olah raga api sucilah yang mampu membakar seluruh karma (Ida Pandita Mpu Nabe Parama Daksa Natha Ratu Bagus, 2012, p.9).

TT: The best kind of sport is the Sared Fire sport; it can burn all our karma (Stacey, 2014, p.9).

'Mampu' in the ST is the lexical item used to express modality of ability. In this context this item has high value of modality. Its modality orientation is objective and implicit. When it is translated into English, the translator translates it literally by using modal verb 'can'. Although both texts express the same interpersonal meaning, there are some changes. The ST modality is in high value, while the TT is in low value. The change of value in the TT indicates that the speaker is less confident in expressing his ability. Other cases are found in the following data

1) ST: Olah raga jiwa ini juga mampu membuat hidup kita sederhana (Ida Pandita Mpu Nabe Parama Daksa Natha Ratu Bagus, 2012, p.9).

TT: This Soul sports also makes our life simple (Stacey, 2014, p.9).

2) ST: Jika kita tidak menemukan cinta, maka bukan cintanya yang salah, tetapi kitalah yang tidak bisa membangun cinta (Ida Pandita Mpu Nabe Parama Daksa Natha Ratu Bagus, 2012, p.28).

TT: If we have not yet found love, it's not love that is to blame, but us who have not yet been able to develop our love (Stacey, 2014, p.29).

\section{E. Inclination}

The lexical items 'ingin', 'berniat' are used to indicate inclination in Indonesian. In English this modality of inclination is expressed by using the verb 'want. The example is:

ST: Inilah mengapa spiritual dikatakan tidak ada. Kemudian dikatakan ada karena kita ingin mencapai kondisi ini (Ida Pandita Mpu Nabe Parama Daksa Natha Ratu Bagus, 2012, p.4).

TT: This is why one may think it does not exist. We could also say that it exists because we want to reach out for it (Stacey, 2014, p.4).

'Ingin' in the ST which is used to express willingness is represented in the TT by using the verb 'want'. The modality of the ST and TT belongs to median, objective and implicit modality. So, both texts have the same modality content and express the same modality meaning. Another example of a text showing modality of inclination is as follows.

ST: Kalau kita berniat untuk membangun jiwa, maka akan banyak sekali yang menggoda dengan seribu macam alasan (Ida Pandita Mpu Nabe Parama Daksa Natha Ratu Bagus, 2012, p.10).

TT: If we have the intention to build up our Soul, we will come up against thousands of temptations and excuses (Stacey, 2014, p.10). 
As the main points, some issues need to be considered dealing with the translatability of Indonesian modality into English. Firstly, although Indonesian and English have different ways in expressing modality, translation equivalence involving modality can be successfully achieved. Modality which refers to the speaker's attitude is expressed by using lexical items in Indonesian, but to some extent it is grammatically expressed in English. Secondly, re-contextualization of modality in translation leads to consequences. The translator may weaken the strength of modality, or vice versa. When 'mampu' which is of high value in Indonesian is rendered into 'can', the value becomes low. Thirdly, as long as the types of modality are concerned, they remain unchanged in English, except for the modal showing usuality 'sering' meaning 'frequently' which is also rendered into modality of probability 'likely'.

\section{CONCLUSION}

Problems of modality can be well handled in the translation of Indonesian text into English. Modality of Indonesian text which is not expressed by using a particular marker is translated in various ways in English. They are expressed by using modal verbs, modal adverbs, adjective, and also implicitly expressed through the use of tense. The effect resulted from the difference in the use of the markers is that the markers may change the value and orientation of modality and this also indicates that there are changes of contextual meanings in the translation. Based on the data analyzed, lexical items expressing particular modality in Indonesian are mostly literally translated into English by applying the strategy of equation. The followings are translation choices suggested to overcome the problem of modality in Indonesian into English translation. Mod stands for modality, IST for Indonesian Source Text and ETT for English Target Text.

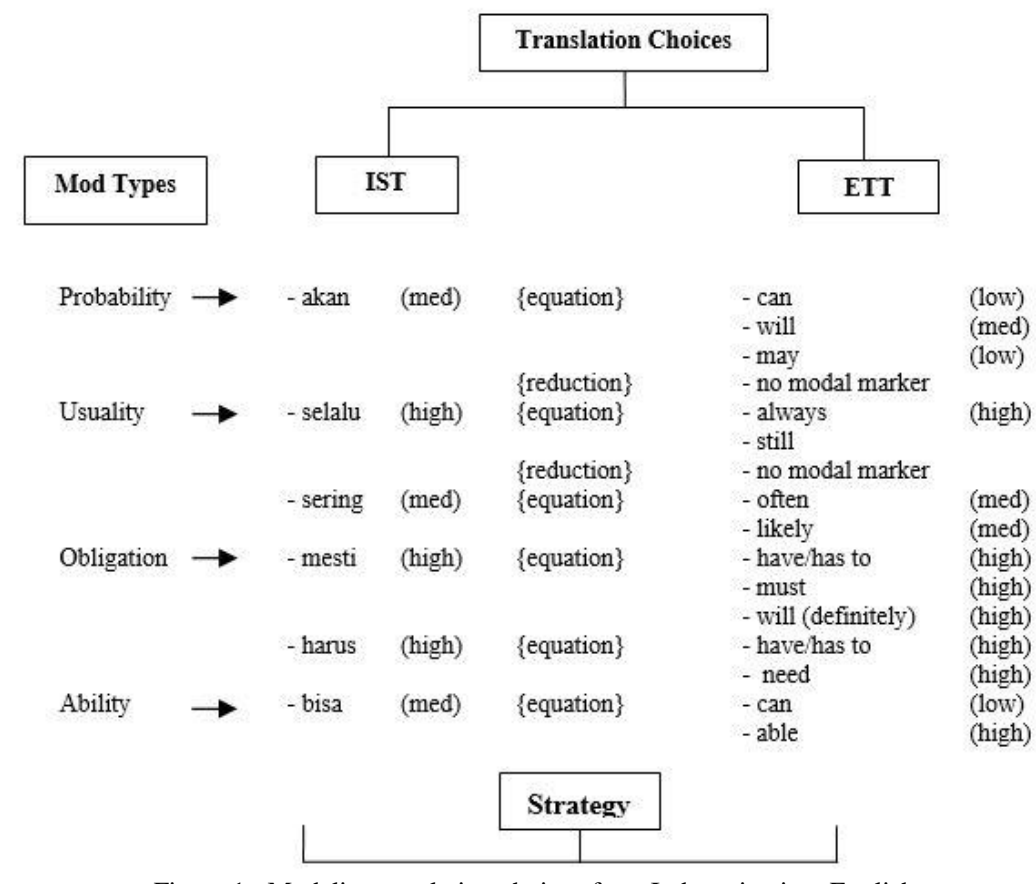

Figure 1. Modality translation choices from Indonesian into English

\section{REFERENCES}

[1] Alwi, H. (1992). Modalitas dalam Bahasa Indonesia. Yogyakarta: Penerbit Kanisius.

[2] Arka, I W. (2016). On modality and finiteness in Indonesian: complexities of =nya nominalisation. Proceedings of the International Workshop on TAM and Evidentiality in Indonesian Language.

[3] Bell, R.T. (1991). Translation and Translating: Theory and Practice. New York: Longman Group UK Limited.

[4] Halliday, M.A.K. \&C.M.I.M., Matthiessen. (2014). Halliday's Introduction to Functional Grammar. Fourth Edition. New York: Routledge.

[5] Hatim, B. \& I. Mason. (1997). The Translator as Communicator. New York: Routledge.

[6] House, J. (2015). Translation Quality Assessment. New York: Routledge.

[7] Ida Pandita Mpu Nabe Parama Daksa Natha Ratu Bagus. (2012). Butir-Butir Kebijaksanaan: Titian HidupSehat dengan Meditasi Bio-Energi Ratu Bagus. ISBN 978-602-18646-0-9. Karangasem: Ashram Ratu Bagus.

[8] Lian, Z.\&T. Jiang. (2014). A Study of Modality System in Chinese-English Legal Translation from the Perspective of SFG. Theory and Practice in Language Studies, Vol. 4, No. 3, pp. 497-503. ISSN 1799-2591. doi: 10.4303/tpls.4.3.497-503.

[9] Malone, J.L. (1988). The Science of Linguistics in the Art of Translation. Albany: State University of New York Pess.

[10] Martin J.R. \&P.R.R., White. (2005). The Language of Evaluation: Appraisal in English. New York: Palgrave Macmillan.

[11] Moindjie, M.A. (2015). The Function of Modality in Translation. International Journal of Comparative Literature and Translation Studies, Vol. 3, No. 2. ISSN 2202-9451. doi: 10.7575/aiac.ijclts.v.3n, 2p.11. 
[12] Saldhana, G. \& O. Sharon. (2014). Research Methodologies in Translation Studies. New York: Routledge.

[13] Stacey, M. (2014). Pearls of Wisdom: The Path of a Healthy Life with Ratu Bagus Bio-Energy Meditation. ISBN 978-60218646-6-1. Karangasem: Ratu Bagus Ashram.

[14] Wang, J., J. Bao, Y. Liu\&Y. Meng. (2015). A Study of English Translation of Yili Products' Advertisements from the Perspective of Pragmatic Equivalence. Theory and Practice in Language Studies, Vol. 5, No. 5, pp. 1072-1077. ISSN 17992591. DOI: http://dx.doi.org/10.17507/tpls.0505.23.

[15] Xia, X. (2015). Meaning in Context and Nature of Translation. Theory and Practice in Language Studies, Vol. 5, No. 3, pp. 652-656. ISSN 1799-2591. DOI: http://dx.doi.org/10.17507/tpls.0503.28.

Made Susini was born in Singaraja, Bali, Indonesia. She is currently a lecturer in English Department at Warmadewa University, Bali, Indonesia. She obtained her Master Degree in Linguistics (Translation) in 2005 from Udayana University, Bali, Indonesia. She is currently a candidate doctorate in Linguistics at Udayana University and her main research focuses on Linguistic Translations.

Ida Bagus Putra Yadnya is a Professor in Linguistics (Translation) at Udayana University, Bali, Indonesia. He received his Master in American Studies from University of Indonesia in 1986 and his Doctorate in Linguistics from Udayana University, Bali, Indonesia in 2004. His research interests include a wide range of topics related to linguistics and language teaching. He has supervised many theses and doctorate dissertations. He has actively participated in numerous national and international conferences and workshops and has written a lot of articles published in national and international journals.

Ida Ayu Made Puspani is a senior lecturer of English Department, Faculty of Arts at Udayana University, Bali, Indonesia. She obtained her Master in Applied Linguistics (Translation) in 2003 and her Doctorate in 2010 also in Applied Linguistics (Trans lation) in 2010. Both were received from Udayana University, Bali, Indonesia. Her research interests are translation and language teaching. Her publications include studies on translation (2013-2014), language teaching for young learners (2011) and court interpreting in Denpasar Court (2010). She has participated in many national and international conferences and workshop. 